\title{
Monoclonal Antibody SGN-14
}

National Cancer Institute

\section{Source}

National Cancer Institute. Monoclonal Antibody SGN-14. NCI Thesaurus. Code C2005.

A humanized monoclonal antibody targ eting the CD40 antigen with potential antineoplastic activity. CD-40, an integral membrane protein found on the surface of B lymphocytes and member of the tumor necrosis factor receptor super-family, is highly overexpressed on the cell surface of a number of B-cell malignancies. Monoclonal antibody SGN-14 specifically binds to and inhibits CD-40, thereby inhibiting cell proliferation and inducing cell lysis via antibody-dependent cellular cytotoxicity (ADCC) in cells. 